\section{PP-033 限局性前立腺癌の手術成績}

\section{高知高須病院泌尿器科 ${ }^{1)}$, 大西病院 ${ }^{2)}$}

松下 和弘 ${ }^{1}$, 中西 良一 ${ }^{1)}$, 甲藤 和伸 ${ }^{1)}$, 大田 和道 ${ }^{1)}$, 杉田 治1), 戦 泰和 ${ }^{1)}$, 湯浅 健司 ${ }^{1)}$, 寺尾 尚民 ${ }^{1)}$, 山本 晶弘 ${ }^{2\rangle}$

【目的】当院に抢汁万限局性前立腺癌に対する恥骨後式根 治的前立腺全摘除術の治療成績ついて検討を行った。【対 象と方法】 2002 年 5 月から現在までに初回治療として手 術単独療法が行われた 115 例を対象とし、術前因子、術 後病理所見とPSA 再発について検討を行った。【結果】 平均年歯 66.1 歳 $(52 \sim 77$ 歳)、平均 PSA7.99 $\mathrm{ng} / \mathrm{m}(2.6$ 〜 40.6ng $/ \mathrm{ml}$ )、臨床病期は T1c 79 例、T2 36 例、生検の Gleason scoreは 6 以下 63 例、 7 が47例、8以上 5 例であった。 術後病理病期は pT2 70 例、pT3 45 例で、切除断端陽性は 46 例 $(40.0 \%)$ であった。術後観察期間は中央值 21.0 ヶ 月 $(2$ ～ 83 ケ月 $)$ で、PSA 再発を 32 例 $(27.8 \%)$ に認め、 3 年 PSA 非再発率 $67.8 \%$ であった。リスク別 3 年 PSA 非 再発率は低リスク群 79.4\%、中リスク群 $64.8 \%$ 、高リスク 群 42.3\%で高リクス群は有意に不良であった。また、病理 病期別 3 年 PSA 非再発率は pT2 70.6\%、pT3 63.1\%、切 除断端浸潤別 3 年 PSA 非再発率は断端陰性群 $79.8 \%$ 、断 端陽性群 $51.7 \%$ で pT3 および切除断端陽性群は有意に不 良であった。【結論】限局性前立腺癌に対する根治的前立 腺全摘除術において高りスク群、pT3 および切除断端陽 性群では PSA 再発が高率であった。

\section{PP-034 大阪労災病院における根治的前立腺全摘 除術症例の治療成績の検討}

\section{大阪労災病院泌尿器科}

任 幹夫, 上田 倫央, 山本 致之, 川村 憲彦,

氏家 剛, 西村 健作, 三好 進

【目的】当院に招ける根治的前立腺全摘除術症例の治療成 績について検討を行う。【対象と方法】1997年1月より 2006 年 12 月までの間に当院にて根治的前立腺全摘除術 を施行し 12 ケ月上上の経過観察が可能であった 165 例を 対象とした。PSA 再発は $0.2 \mathrm{ng} / \mathrm{ml}$ を越えた時点とした。 TNM 分類は 2002 年改訂第 6 版に準じた。生存率、PSA 非再発率は Kaplan-Meier 法にて算出し、有意差検定は Log-rank 法を用いた。【結果】年齢は $52-78$ 歳（中央值 68.5 歳)。診断時 PSA は $3.1-320 \mathrm{ng} / \mathrm{ml}$ (中央值 $11.0 \mathrm{ng}$ / $\mathrm{ml}$ )。術後観察期間は $13-136$ ヶ月（中央值 55 ヶ月）。 臨床病期は T1 が 54 例、T2 が 89 例、T 3 が 21 例、T 4 が 1 例。組織学的分類は高分化型が 60 例、中分化型が 78 例、 低分化型が 25 例。術前内分泌療法を 95 例に施行した。病 理学的病期は pT0 が 8 例、pT2 が 117 例、p T 3 が 36 例、 p T 4 が 4 例。切除断端陽性を 25 例に認め、所属りンパ 節転移を 6 例に認めた。術後即時療法（内分泌療法または 放射線療法）を 13 例に施行した。死亡を 8 例（他因死 5 例、癌死 3 例）に認めた。PSA 再発を 65 例に認め、再発 までの期間は 0-124 ケ月（中央值 20.3 ケ）であった。 5 年 $/ 10$ 年全生存率は $93.9 / 93.9 \% 、 5$ 年 $/ 10$ 年疾患特異 生存率は $98.0 / 98.0 \% 、 5$ 年 $/ 10$ 年 PSA 非再発率は 63.6 / 40.2\%であった。術後PSA 再発について、さまざまな 因子につき検討を加える。

\section{PP-035}

岩手県立大船渡病院泌尿器科における根 治的前立腺全摘除術症例の治療成績と PSA 再発症例の検討

\section{岩手県立大船渡病院泌尿器科 ${ }^{1)}$, 岩手医科大学泌尿器科 ${ }^{2)}$, 岩手県立中央病院泌尿器科 ${ }^{3}$, 北上済生会病院泌尿器科 ${ }^{4)}$, 岩手県立大船渡病院病理科 ${ }^{5)}$}

井筒 俊利 ${ }^{12}$, 赤坂 俊太郎 ${ }^{2}$, 瀬尾 崇 ${ }^{2}$, 岩動 一将 ${ }^{3)}$, 田村 健文, 中村 泰行 ${ }^{5}$ 。 氏家 隆 ${ }^{1)}$

【目的】岩手県立大船渡病院泌尿器科で限局性前立腺癌に 対し根治的前立腺全摘除術施行された症例の手術成績と PSA 再発症例の臨床病理学的特徵について検討した。【万 法】1999 年 4 月から 2009 年 3 月までに限局性前立腺癌と 診断され、初回治療として手術単独療法が行われ経過観察 可能であった 166 例を対象とした。症例の臨床病理学的因 子と生存率、PSA 再発率を調査した。さらにPSA 再発症 例の臨床病理学的特徴を解析した。【結果】手術時平均年 齢 68 歳 $(53 \sim 80$ 歳)。生検時平均 PSA8.18ng $/ \mathrm{ml} \quad(1 \sim$ $31.1 \mathrm{ng} / \mathrm{ml})$ 。術後平均観察期間 51.6 ヶ月 $(1.1 \sim 124.9$ ヶ 月)。摘出標本 Gleason score は 6 以下 : 94 例、 $7: 35$ 例、 8 以上: 37 例。病理学的病期は $\mathrm{pT} 2 \mathrm{a}: 47$ 例、 $\mathrm{pT} 2 \mathrm{~b}: 71$ 例、pT3a：27 例、pT3b：21 例、pN1：10 例。病理学的 進展度は被膜外浸潤 : 50 例、外科的切除断端陽性：75 例、 リンパ管浸潤陽性：65 例、血管浸潤陽性：71 例、神経線 維周囲浸潤陽性：112 例、精囊浸潤陽性：19 例、㲾道粘膜 浸潤陽性：11 例。観察期間中に癌死症例なく、他因死を 6 例（3.6\%）認めた。また術後PSA 再発は 43 例（25.9\%） であった。さらにPSA 再発を来した症例について臨床病 理学的因子との相関解析を報告する予定である。

\section{PP-036＼cjkstart前立腺全摘除術症例におけるリンパ管脈 管浸潤の PSA 再発への影響}

函館五稜郭病院泌尿器科 ${ }^{1)}$, 札幌医科大学医学部泌尿器科 ${ }^{2)}$ 高橋 敦 ${ }^{1)}$, 高柳 明夫 ${ }^{11}$, 上原 央久 ${ }^{12}$, 佐藤 俊介 ${ }^{1 ?}$, 市原 浩司 ${ }^{21}$, 高木 良雄 ${ }^{21}$

【目的】前立腺全摘除術症例におけるリンパ管脈管浸潤 (LVI) のPSA 再発への影響について検討した。【対象と 方法】1997 年〜 2008 年に函館五稜郭病院泌尿器科で臨床 的限局癌に対して前立腺全摘除術を施行した 212 例中、術 前後補助療法を施行した症例を除く 168 例を対象とした。 $\mathrm{PSA}$ 再発は $\geqq 0.2 \mathrm{ng} / \mathrm{ml}$ と定義した。【結果】手術時年齢 の平均は 67.5 歳で、手術前 PSA は中央值 $9.2 \mathrm{ng} / \mathrm{ml}(1.6$ 〜 76.0) であった。経過観察期間中 (中央值: 41.2 力月 $(6.0$ 〜 140))、PSA 再発を認めたのは 53 例 (31\%) であった。 全摘標本中 LVI は 41 例 (24\%) に存在し、そのうち 24 例 （59\%）にPSA 再発を認めた。24 例のPSA 再発までの期 間は、中央值 9.8 カ月 (0-41) と早期であった。LVIを含 めたPSA 再発予測因子の検討では、単变量解析において 術前 PSA、全摘時 Gleson Score (GS)、病理病期、被膜浸潤、 切除断端陽性、精囊浸潤、LVIが有意であった。多変量解 析（Cox 比例ハザードモデル）では、LVI、切除断端陽性、 GS の順で有意にPSA 再発に関与していた。これらの 3 因 子のうち因子数 0 個群 (52 例)、1 個群 (69 例)、2-3 個群 (46 例) 05 年 PSA 非再発率はそれぞれ 90\%、67\%、28\% と各群間に有意差を認めた。【結論】LVIは重要な PSA 再 発予測因子であり、術後補助療法を考慮する上で重要な因 子になるものと思われた。 